\title{
Dövizin Borsa İstanbul Pay Piyasasında Yatırım Yapan Yatırımcılar Tarafından Koruma Amaçlı Olarak Kullanılmasının Etkinliği
}

(Araştırma Makalesi)

The Effectiveness of Using Foreign Exchange as a Hedge Mechanism by Investors in Borsa Istanbul Stock Exchange

Doi: 10.29023/alanyaakademik.817412

\section{Serkan ÜNAL}

Dr. Ögr.Görevlisi, Ufuk Üniversitesi, Meslek Yüksek Okulu

serkan.unal@ufuk.edu.tr

Orcid No:0000-0002-7060-979X

How to cite this article: Ünal, S. (2021). "Dövizin Borsa İstanbul Pay Piyasasında Yatırım Yapan Yatırımcılar Tarafindan Koruma Amaçlı Olarak Kullanılmasının Etkinliği”, Alanya Akademik Bakış, 5(1), Sayfa No. 245-263.

\author{
Anahtar kelimeler: \\ Dolar, Döviz, BIST100, \\ Borsa, Hedge \\ Mekanizması
}

Makale Geliş Tarihi:

28.10.2020

Kabul Tarihi:

25.11.2020

Keywords:

Dollar, Foreign

Exchange, BIST100,

Stock Exchange,

Hedge Mechanism

\section{ÖZET}

Bu çalışmada Borsa Ístanbul'da yatırım yapan yatırımcıların dövizi bir hedge mekanizması olarak kullanıp kullanamayacakları araştırılmıştır. Regresyon analizleriyle reel USDTRY kuru ve reel BIST100 endeksi arasındaki ilişkinin test edildiği çalışma 1994 ve 2020 yılları arasını kapsamaktadır. Bu zaman aralığında, iki değişken arasındaki uzun vadeli ilişsi ve 1994, 2001, 2008 ve 2018 krizleri sirasındaki ilişkiler incelenmiştir. Elde edilen bulgulara göre reel USDTRY kuru ile reel BIST100 endeksi arasında ters yönlü ve güçlü bir ilişki söz konusudur. Özellikle BIST100 endeksine uzun vadeli yatırım yapan yatırımcılar için geçmişte yaşanan ani kriz ortamlarında USDTRY kuru önemli derecede hedge fonksiyonunu yerine getirmiştir.

\footnotetext{
ABSTRACT

In this study, it is investigated whether investors investing in Borsa Istanbul can use the exchange rate as a hedging mechanism. The study, in which the relationship between the real USDTRY rate and the real BIST100 index is tested with regression analysis, covers the years between 1994 and 2020. In this time span, the long-term relationship between the two variables and the relationships during the 1994, 2001, 2008, and 2018 crises were examined. According to the findings obtained, there is a strong and inverse relationship between the real USDTRY rate and the real BIST100 index. Especially for investors who made long-term investments in the BIST100 index, the USDTRY rate has fulfilled its hedge function significantly in the sudden crisis environment experienced in the past.
} 


\section{GİRIŞ}

21. yüzyıl başlarında gelişmiş ülkelerde nüfus yaşlanmış, ekonomik büyüme hızı yavaşlamış ve ihracat ve iç talepte durulma yaşanmıştır. Bu koşullar, düşük enflasyon ve negatif faiz koşullarının oluşmasına neden olmuştur (Abhyankar, 2020:58). Dünya genelinde sabit getirili tahvillerin kazanç oranlarındaki düşüş, yatırımcıların farklı enstrümanlara yönlenmesine neden olmuştur. Bu dönemde Türkiye, çift haneli seyreden enflasyon hızı (TUİK, 2020) ve döviz kurlarındaki yüksek oynaklık ile diğer ülkelerden ayrışmıştır (Karabıyık ve Çılbant, 2020:9). Özellikle 2019 sonrasında TCMB, politika faiz oranını Eylül 2018'de \%24 iken Mayıs 2020'de \%8,25'e kadar düşürmüş (TCMB, 2020) ve kamu bankaları öncülüğünde Temmuz 2019'dan Ağustos 2020'ye kadar geçen sürede bankacıllk sektörünün vermiş olduğu kredilerde \%40 oranında artış yaşanmıştır (BDDK, 2020). Bu durum, piyasadaki likiditeyi ciddi miktarda artırırken, düşük faiz oranları nedeniyle yatırımcılar farklı yatırım enstrümanları arayışına girmiştir. BIST100 endeksindeki şirketlere yatırım yapan yerli yatırımcı sayısı 2019 yılı Aralık ayında 0.98 milyon adet iken 2020 yılı Temmuz ayında 1,26 milyon adete yükselmiştir (Merkezi Kayıt Kuruluşu, 2020). Türkiye'de günümüzde de çift haneli enflasyonun devam etmesi ve hisse senetlerinin diğer yatırım enstrümanlarına kıyasla daha oynak bir yapıya sahip olması, Türk yatırımcılar için riskten korunmanın önemini artırmaktadır. Bu çalışmada USDTRY (Dolar / TL) kurunun Borsa İstanbul'daki hisse senedi yatırımcıları için bir koruma aracı olarak ne derece etkin olduğu araştırılmıştır. Günümüzde yabancı yatırımcılar, Borsa İstanbul'da \%50 pay sahibidir (Merkezi Kayıt Kuruluşu, 2020). $\mathrm{Bu}$ nedenle Borsa İstanbul'daki hisse senetlerinin yükselişi özellikle yabancı yatırımcıların Türkiye'ye yöneldiği sırada gerçekleşmekte, tam tersi durumda ise hisse fiyatlarında baskılanma gerçekleşmektedir. Yabancı yatırımcılar Türkiye'ye gelirken döviz bozmakta, çıkarken ise döviz almaktadırlar. Bu durum hisse senetleri fiyatları ile döviz kurları arasında ters ilişki oluşturabilir. Diğer yandan Türk borsasındaki birçok şirketin döviz cinsinden borcu söz konusudur (Akkas, 2016:84).

Döviz kurlarındaki yükselme ülkenin risk primini artırmakta, döviz borcu olan şirketlerin sermaye yapılarının bozulmasına yol açmakta ve şirketlerin borçlanma yeteneklerini sınırlamaktadır. Ekonomide iyileşme yaşanan dönemlerde ise bunun tam tersine borsadaki yabancı iştahı artmakta, yurt dışından gelen sermaye akışı ile döviz kurları düşmekte, döviz borcu olan şirketlerin borç oranları iyileşmekte ve şirketlerin piyasa değerleri yükselmektedir. $\mathrm{Bu}$ çalışmada iki farklı değişken arasındaki bu ilişkinin düzeyinin incelenmesi amaçlanmış ve yatırımcılara yatırım kararlarında faydalanabilecekleri bilgi sunulmuştur.

Literatürdeki çalışmalar incelendiğinde önemli bir bölümünün USDTRY kuru ile borsa endeksi arasında aynı yönlü ilişki olduğunu saptadığı görülmektedir (Alacahan ve Akarsu, 2019; Boyacıŏlu ve Çürük, 2016; Hersi ve Koy, 2020; Kayral, 2020). Yeni TÜFE zaman serisinin takip edilmeye başlandığı 2003 yılı Ocak ayından 2020 Ekim ayına kadar geçen sürede USDTRY kuru \%378 ve BIST100 endeksi \%963 oranında artmıştır. Fakat bu artışta aynı dönemde TÜFE'de gerçekleşen \%404'lük önemli seviyedeki yükselişin payı olduğu görülmektedir. Bu da haliyle USDTRY kuru ile BIST100 endeksi arasında pozitif ilişki varmış gibi görünmesine yol açmıştır. Oysa enflasyonun olmadığı bir ortamda bu ilişkiyi gözlemlemek çok daha sağlıklı olacaktır. Diğer yandan literatürdeki çalışmalardan negatif ilişki bulmuş olan Belen ve Karamelekli (2016) ve Türsoy (2017) ise reel kur kullanmışlardır. Reel kur kullanılırken BİST100 endeksinden enflasyon etkisinin ayrıştırılmaması denklemin bir ayağının eksik olmasına yol açmaktadır. Bu çalışmanın literatüre katkıları şu şekilde 
özetlenebilir. (1) Literatürdeki çalışmalardan farklı olarak hem USDTRY kuru için hem de BİST100 endeksi için TÜFE'den arındırılmış veriler kullanılmıştır. Bu sayede doğrudan yatırımcıların faydalanabileceği bir ilişki tanımlanmaya çalışılmıştır. (2) Bu çalışmada 1994 ile 2020 yılları arasındaki geniş bir zaman aralığı dikkate alınarak 1994, 2001, 2008 ve 2018 krizleri sırasında test edilen ilişkinin nasıl gerçekleştiğini analiz etmek mümkün olmuştur. (3) Türkçe literatürdeki çalışmalarda ağırlıklı olarak nedensellik ilişkisi tespit edilmeye çalışılmıştır. Bu çalışmada ise reel dolar kuru ve reel BIST100 endeksi arasında uzun dönemde eşbütünleşme olmadığı tespit edilmiş ve Tsai'nin (2012) Asya ülkelerinde kullandığı metodoloji izlenerek regresyon analizi yapılmıştır. Regresyon analizleri üç aşamada uygulanmıştır. İlk olarak aylık frekansta uzun dönemli ilişki test edilmiştir. İkinci olarak kriz dönemlerindeki ilişkinin daha detay analiz edilebilmesi için haftalık frekansta modeller oluşturulmuş ve her bir kriz dönemi ayrı ayrı analiz edilmiştir. Son olarak, USDTRY kuru getirileri yüzdelik dilimlere ayrılmış ve USDTRY kurunun yükseldiği ve düştüğü dönemlerde ilişkinin ne kadar sağlıklı gerçekleştiği regresyon analizleri ile ayrı ayrı test edilmiştir.

$\mathrm{Bu}$ makalede araştırma ve yayın ilkelerine uyulmuştur. Makalenin hazırlanması sırasında halka açık veriler kullanılmış olup etik kurul izni ve/veya yasal/özel izin alınması gerekli değildir.

\section{DÖVIZ KURLARI İLE BORSA PERFORMANSLARI ARASINDAKİ ILISSKIYYI İNCELEYEN ÇALIŞMALAR}

Literatürde döviz kuru ile borsa getirileri arasındaki ilişki oldukça sıklıkla çalışılan konulardan biridir. Farklı ülke borsalarında yapılmış araştırmalarda farklı sonuçlar elde edildiği görülmektedir (Bkz. Tablo 1). Son dönemde yapılmış olan çalışmalar ise aşağıda özetlenmiştir.

Çevik ve Çankaya (2020) 2008 ve 2019 yılları arasında altı farklı ülkeyi kapsayan çalışmalarında ülkelere ait borsa endeksleri, yabancı alımları ve döviz kurları arasındaki ilişkiyi analiz etmişlerdir. Araştırmada üç farklı ARDL modeli kurularak her bir değişken hem bağımlı hem de bağımsız değişken olarak kullanılmıştır. Araştırmadan elde edilen bulgulara göre uzun vadede Hindistan ve Türkiye'de döviz kurları borsa endeksini artırıcı yönde etki etmektedir.

Hersi ve Koy (2020) kırılgan beşli ülkelerini ele aldıkları çalışmalarında 2010 ve 2019 yılları arasında döviz kurları ve borsa endeksleri arasındaki ilişkiyi analiz etmişlerdir. VAR analizi ve Granger nedensellik testlerinin uygulandığı çalışmada Güney Afrika ve Türkiye'de döviz kurları ve borsa endeksleri arasında pozitif yönlü ilişki bulunduğu, Hindistan ve Brezilya'da ise döviz kurundan borsa endeksine doğru tek yönlü bir ilişki olduğu tespit edilmiştir.

Xie, Chen ve Wu (2020), 20 gelişmiş ve 6 gelişmekte olan dünya ülkesine ait 1998 ile 2017 yılları arasındaki veriyi dahil ettikleri çalışmalarında döviz kurları ile borsa endeksleri arasındaki ilişkiyi incelemişlerdir. Elde ettikleri bulgulara göre hisse senedi fiyatları kurları tahmin etme noktasında etkindirler fakat bunun tersi geçerli değildir. Nedensellik incelendiğinde ise kurlarla endeksler arasında karşılıklı ama zayıf bir ilişki söz konusudur.

Kayral (2020), 2009 ve 2019 yılları arasındaki Borsa İstanbul şehir endeksleri ve döviz kurları arasındaki ilişkiyi analiz etmiştir. ARDL sınır testinin kullanıldığı çalışmada İstanbul, Ankara ve İzmir şehir endeksleri ile döviz kurları arasında eş bütünleşme olduğu tespit 
edilmiştir. Araştırma bulgularına göre Euro ve dolar kurlarındaki \%1'lik artış, İzmir şehir endeksini sirasıyla \%0,84 ve \%0,71 oranlarında etkilemektedir.

Alacahan ve Akarsu (2019) BIST100 endeksi ile döviz kurları arasındaki ilişkiyi 2004 ve 2018 yılları arasındaki veriyi kullanarak incelemişlerdir. Araştırma bulgularına göre USDTRY kuru gecikmeli olarak BIST100 endeksine etki etmektedir.

İlarslan (2018) 2007 ve 2016 yılları arasındaki veriyi kullanarak USDTRY ve EURTRY kurları ve BIST100 endeksi arasındaki ilişkiyi analiz etmiştir. Araştırma bulgularına göre döviz kurları ile Borsa İstanbul arasında bir yıl ile dört yıl arasındaki kısa dönemde negatif dört yıldan daha fazla olan uzun dönemde ise pozitif ilişki bulunmaktadır. Çalışma bulguları Türkiye'de borsa ile döviz kurları arasında geleneksel yaklaşımın geçerli olduğunu belirtmektedir.

Polat (2018) OECD üyesi olan ülkeleri ele aldığı çalışmasında 2000 ile 2016 yılları arasındaki veriyi kullanmış ve döviz kurları ile şirketlerin piyasa değeri arasındaki ilişkiyi analiz etmiştir. Çalışma sonuçlarına göre 1 ülkede döviz kurlarının hisse senetleri fiyatları üzerinde anlamlı etkisi bulunmazken, 11 ülkede pozitif etki, 7 ülkede ise negatif etkinin söz konusu olduğu tespit edilmiştir.

Eyüboğlu ve Eyüboğlu (2018) Borsa İstanbul şehir endeksleri ve BIST100 endeksi ile döviz kurları arasındaki ilişkiyi araştırmıştır. ARDL modeli ile 2011 ve 2016 yılları arasındaki verinin incelendiği çalışmada 24 endeks arasında yalnızca tekstil, deri endeksi ile Euro kuru arasında ve tekstil, deri, ticaret ve teknoloji endeksleri ile dolar kuru arasında kısa dönemde negatif, uzun dönemde ise pozitif ilişki olduğu saptanmıştır.

Tsai (2012) Asya piyasalarında yaptığı araştırmada 1992 ve 2009 yılları arasındaki veriyi kullanarak hisse senedi endeksleri ile döviz kurları arasındaki ilişkiyi analiz etmiştir. Bu araştırmada klasik en küçük kareler yöntemi yerine, yüzdesel dilimler baz alınarak uygulama yapılmıştır. Dolar kurunun değişim değerlerine göre büyükten küçüğe yüzdesel dilimler oluşturulmuş; daha sonrasında her bir yüzdesel dilim için ayrı model kurularak dolar kurundaki değişim ile borsa endeksleri arasındaki ilişki test edilmiştir. 6 farklı Asya ülkesinin dahil edildiği çalışmada, değişik yüzdelik dilimlerde istikrarlı ve istatistiksel olarak anlamlı bir şekilde döviz kuru ile borsa endeksleri arasın negatif ilişki olduğu tespit edilmiştir.

Tablo 1. Döviz Kuru ile Borsa Arasındaki İlişsiyi İnceleyen Çalışmalar

\begin{tabular}{lcccc}
\hline \multicolumn{1}{c}{ Makale } & Yöntem & Kapsam & Dönem & Sonuç \\
\hline Hersi ve Koy (2020) & GC & $\begin{array}{c}\text { GA, TR, EN, HN, } \\
\text { BR }\end{array}$ & $\begin{array}{c}2010- \\
2019\end{array}$ & $\begin{array}{c}\text { GA, TR: Çift Yönlü } \\
\text { HN, BR: FX > Borsa }\end{array}$ \\
\hline $\begin{array}{l}\text { Xie, Chen ve Vu } \\
(2020)\end{array}$ & GC & $\begin{array}{c}\text { 26 farklı gelişmiş } \\
\text { ve gelişmekte } \\
\text { olan ülke }\end{array}$ & $\begin{array}{c}1998- \\
2019\end{array}$ & Çift yönlü ilişki \\
\hline $\begin{array}{l}\text { Çevik ve Çankaya } \\
(2020)\end{array}$ & ARDL & HN, BR, GK, & $\begin{array}{c}2008- \\
\text { EN, TR, GA }\end{array}$ & HN ve TR: FX > Borsa \\
\hline $\begin{array}{l}\text { Emsen, } \\
\begin{array}{l}\text { Sadeghzadeh ve } \\
\text { Aksu (2019) }\end{array}\end{array}$ & ARDL & İR, Reel kur & $2000-$ & Pozitif ilişki \\
\hline
\end{tabular}


ALANYA AKADEMIK BAKIŞ DERGİSİ 5/1 (2021)

\begin{tabular}{|c|c|c|c|c|}
\hline Polat (2018) & AMG ve EK & $\begin{array}{l}\text { OECD üyesi } \\
\text { ülkeler }\end{array}$ & $\begin{array}{l}2000- \\
2016 \\
\end{array}$ & Çift yönlü ilişki \\
\hline Aydın (2017) & $\begin{array}{l}\text { Hacker-Hatemi- } \\
\mathrm{j}\end{array}$ & $\begin{array}{l}\mathrm{AR}, \mathrm{BR}, \mathrm{CH}, \mathrm{EN}, \\
\text { Fİ, MK, TR }\end{array}$ & $\begin{array}{l}1995- \\
2016\end{array}$ & Borsa $>$ FX \\
\hline Sui ve Sun (2016) & ARDL & $\begin{array}{l}\text { BR, RS, HN, CH, } \\
\text { GA }\end{array}$ & $\begin{array}{l}1993- \\
2014\end{array}$ & $\begin{array}{c}\text { Kisa vadede } \mathrm{FX}> \\
\text { Borsa }\end{array}$ \\
\hline $\begin{array}{l}\text { Akıncı ve } \\
\text { Küçükçaylı (2016) }\end{array}$ & GC & $\begin{array}{c}\text { TR, AVS, KA, } \\
\text { DA, JP, IS, İN, } \\
\text { AL, FR, FN, BL, } \\
\text { AV }\end{array}$ & $\begin{array}{l}1997- \\
2013\end{array}$ & Negatif ilişki \\
\hline $\begin{array}{l}\text { Najaf ve Najaf } \\
(2016)\end{array}$ & GC & $\mathrm{HN}$ & $\begin{array}{l}2007- \\
2009 \\
\end{array}$ & Borsa $>$ FX \\
\hline İnci ve Lee (2014) & GC & $\begin{array}{l}\text { FR, AL, IT, İS, } \\
\text { İN }\end{array}$ & $\begin{array}{l}1984- \\
2009 \\
\end{array}$ & Çift yönlü ilişki \\
\hline $\begin{array}{l}\text { Tsagkanos ve } \\
\text { Siriopoulos (2013) }\end{array}$ & GC & US ve EU & $\begin{array}{l}2008- \\
2012\end{array}$ & Borsa $>$ FX \\
\hline $\begin{array}{l}\text { Kisaka ve Mwasaru } \\
\text { (2012) }\end{array}$ & GC & $\mathrm{KE}$ & $\begin{array}{l}1993- \\
1999\end{array}$ & $\mathrm{FX}>$ Borsa \\
\hline Tsai (2012) & EKK & $\begin{array}{c}\text { SN, GK, Fİ, TA, } \\
\text { TY }\end{array}$ & $\begin{array}{l}1992- \\
2009\end{array}$ & Negatif ilişki \\
\hline $\begin{array}{l}\text { Walid, Chaker, } \\
\text { Masood ve Fry } \\
\text { (2011) }\end{array}$ & EGARCH & $\begin{array}{c}\mathrm{HK}, \mathrm{SN}, \mathrm{MA}, \\
\text { MK }\end{array}$ & $\begin{array}{l}1994- \\
2009\end{array}$ & $\mathrm{FX}>$ Borsa \\
\hline Tian ve Ma (2010) & ARDL & $\mathrm{CH}$ & $\begin{array}{l}1995- \\
2009 \\
\end{array}$ & Pozitif ilişki \\
\hline Dimitrova (2005) & GC & $\mathrm{BD}, \mathrm{IIN}$ & $\begin{array}{l}1990- \\
2004\end{array}$ & $\begin{array}{l}\text { Aynı yönlü fakat zayıf } \\
\text { ilişki bulunmuştur }\end{array}$ \\
\hline $\begin{array}{l}\text { Ramasamy ve } \\
\text { Yeung (2005) }\end{array}$ & $\mathrm{GC}$ & $\begin{array}{l}\text { HK, Fİ, MA, Sİ, } \\
\text { TY, GK }\end{array}$ & $\begin{array}{l}1997- \\
2000\end{array}$ & $\begin{array}{c}\text { HK: Çift yönlü } \\
\text { Fİ, MA, Sİ, TY: Borsa } \\
\text { > FX GK: FX > Borsa }\end{array}$ \\
\hline $\begin{array}{l}\text { Smyth ve Nandha } \\
\text { (2003) }\end{array}$ & GC & BA, HN, PK, SL & $\begin{array}{l}1995- \\
2001\end{array}$ & HN: FX > Borsa \\
\hline $\begin{array}{l}\text { Hatemi-J ve } \\
\text { Irandoust (2002) }\end{array}$ & GC & İS & $\begin{array}{l}1993- \\
1998\end{array}$ & Borsa $>$ FX \\
\hline $\begin{array}{l}\text { Granger, Huangb ve } \\
\text { Yang (2000) }\end{array}$ & GC & $\begin{array}{l}\text { HK, EN, JP, GK, } \\
\text { MA, FI, Sİ, TY, } \\
\text { TA }\end{array}$ & $\begin{array}{l}1986- \\
1997\end{array}$ & $\begin{array}{c}\text { GK: FX -> Borsa } \\
\text { HK ve Fİ: Borsa > FX } \\
\text { MA, Sİ, TA, TY: Çift } \\
\text { yönlü }\end{array}$ \\
\hline Demirkale (2020) & GC & TR: BIST100 & $\begin{array}{l}2005- \\
2019\end{array}$ & $\mathrm{FX}>$ Borsa \\
\hline Kayral (2020) & ARDL & $\begin{array}{l}\text { TR: Şehir } \\
\text { endeksleri }\end{array}$ & $\begin{array}{l}2009- \\
2019\end{array}$ & Pozitif ilişki \\
\hline
\end{tabular}




\begin{tabular}{|c|c|c|c|c|}
\hline $\begin{array}{l}\text { Alacahan ve Akarsu } \\
\text { (2019) }\end{array}$ & ARIMA & TR: BIST100 & $\begin{array}{l}2004- \\
2018\end{array}$ & Pozitif ilişki \\
\hline $\begin{array}{l}\text { Şahin ve Özkan } \\
\text { (2018) }\end{array}$ & Eş bütünleşme & TR: BIST100 & $\begin{array}{l}2012- \\
2017\end{array}$ & İlişki yok \\
\hline İlarslan (2018) & Bayes & TR: BIST100 & $\begin{array}{l}2007- \\
2016\end{array}$ & $\begin{array}{l}\text { Kisa vade negatif; } \\
\text { Uzun vade pozitif }\end{array}$ \\
\hline $\begin{array}{l}\text { Eyüboğlu ve } \\
\text { Eyüboğlu (2018) }\end{array}$ & ARDL & $\begin{array}{l}\text { TR: BIST100 ve } \\
\text { diğer endeksler }\end{array}$ & $\begin{array}{l}2011- \\
2016\end{array}$ & $\begin{array}{l}\text { Kisa vade ters yönlü; } \\
\text { Uzun vade aynı yönlü }\end{array}$ \\
\hline Türsoy (2017) & ARDL ve GC & TR: BIST100 & $\begin{array}{l}2001- \\
2016 \\
\end{array}$ & Negatif ilişki \\
\hline $\begin{array}{l}\text { Belen ve } \\
\text { Karamelekli (2016) }\end{array}$ & ARDL & TR: BIST100 & $\begin{array}{l}2006- \\
2014\end{array}$ & Negatif ilişki \\
\hline $\begin{array}{l}\text { Boyacıoğlu ve } \\
\text { Çürük (2016) }\end{array}$ & $\begin{array}{l}\text { Havuzlanmış } \\
\text { EKK }\end{array}$ & $\begin{array}{l}\text { TR: İmalat sanayi } \\
\text { firmaları }\end{array}$ & $\begin{array}{l}2006- \\
2014\end{array}$ & Pozitif ilişki \\
\hline $\begin{array}{l}\text { Kendirli ve } \\
\text { Çankaya (2016) }\end{array}$ & GC & TR: BIST30 & $\begin{array}{l}2009- \\
2014\end{array}$ & FX $>$ Borsa \\
\hline $\begin{array}{l}\text { Şahin ve Sekmen } \\
\text { (2013) }\end{array}$ & ARCH/GARCH & $\begin{array}{c}\text { TR: } 5 \text { şirkete ait } \\
\text { veri }\end{array}$ & $\begin{array}{l}1986- \\
2012\end{array}$ & FX $>$ Borsa \\
\hline $\begin{array}{l}\text { Kaya, Çömlekçi ve } \\
\text { Kara (2013) }\end{array}$ & EKK & TR: BIST100 & $\begin{array}{l}2002- \\
2012\end{array}$ & Negatif ilişki \\
\hline İşcan (2011) & GC & TR: BIST100 & $\begin{array}{l}2001- \\
2009\end{array}$ & Borsa $>$ FX \\
\hline $\begin{array}{l}\text { Özer, Kaya ve Özer } \\
\text { (2011) }\end{array}$ & GC & TR: BIST100 & $\begin{array}{l}1996- \\
2009\end{array}$ & $\begin{array}{c}\text { Kisa vadede } \mathrm{FX}> \\
\text { Borsa }\end{array}$ \\
\hline $\begin{array}{l}\text { Doğukanl, Özmen } \\
\text { ve Yücel (2010) }\end{array}$ & JET & $\begin{array}{l}\text { TR: Sektörel } \\
\text { Endeksler }\end{array}$ & $\begin{array}{l}1999- \\
2009\end{array}$ & $\begin{array}{l}\text { Hizmet sektörü negatif; } \\
\text { Mali ve sınai pozitif } \\
\text { ilişki }\end{array}$ \\
\hline $\begin{array}{l}\text { Aydemir ve } \\
\text { Demirhan (2009) }\end{array}$ & TY & $\begin{array}{l}\text { TR: BIST100 ve } \\
\text { diğer endeksler }\end{array}$ & $\begin{array}{l}2001- \\
2008\end{array}$ & Negatif ilişki \\
\hline $\begin{array}{l}\text { Rjoub, Türsoy ve } \\
\text { Günsel (2009) }\end{array}$ & EKK & $\begin{array}{l}\text { TR: } 193 \text { farklı } \\
\text { şirket }\end{array}$ & $\begin{array}{l}2001- \\
2005\end{array}$ & $\begin{array}{l}\text { Sektörel bazda negatif } \\
\text { ve pozitif ilişkiler }\end{array}$ \\
\hline Ayvaz (2006) & GC & TR: BIST100 & $\begin{array}{l}1991- \\
2004 \\
\end{array}$ & Çift yönlü ilişki \\
\hline $\begin{array}{l}\text { Karamustafa ve } \\
\text { Küçükkale (2002) }\end{array}$ & GC & TR: BIST100 & $\begin{array}{l}2000- \\
2001\end{array}$ & Borsa $>$ FX \\
\hline
\end{tabular}

Ülkeler: AV: Avustralya; AL: Almanya; AR:Arjantin; AV: Avusturya; AVS: Avustralya; BA: Bangladeş; BD: Birleşik Devletler; BL: Belçika; BR: Brezilya; CH: Çin; EN: Endonezya; EU: Avrupa Birliği; Fİ: Filipinler; FN: Finlandiya; FR: Fransa; GA: Güney Afrika; GK: Güney Kore; HN: Hindistan; HK: Hong Kong IN: Ingiltere; IR: Iran; IS: Ísviçre; IT: Ittalya; JP: Japonya; KA: Kanada; KE: Kenya; MA: Malezya; MK: Meksika; PK: Pakistan; RS: Rusya; SL: Sri Lanka; SN: Singapur; TY: Tayland; TA: Tayvan; TR: Türkiye; US: Birleşik Devletler 
Yöntemler: GC: Granger nedensellik testi; EK: Emirmahmutoglu-Kose testi; EKK: En küçük kareler; TY: Toda-Yamamoto; JET: Johensen eş bütünleşme testi

Borsa > FX: Borsa endeksinden döviz kurlarına; FX > Borsa : Döviz kurlarından borsa endeksine doğru ilişki olduğunu belirtmektedir.

Kaynak: Yazar tarafindan oluşturulmuştur.

\section{VERI VE YÖNTEM}

Bu çalışmada 1994 Ocak ile 2020 Temmuz arasında BIST100 endeksi, USDTRY kuru ve TÜFE verisi kullanılmıştır. BIST100 endeks verisi Borsa İstanbul internet sitesinden, USDTRY kuru TCMB'den ve TÜFE verisi ise TUİK'den temin edilmiştir. Doların rezerv para birimi oluşu ve Borsa İstanbul'da en büyük paya sahip olan yatırımcıların ABD kökenli oluşu (Bloomberght, 2020) nedeniyle araştırmada kullanılacak döviz birimi olarak dolar seçilmiştir. 2001 yılına kadar Türkiye'de sabit döviz kuru rejimi uygulanması (Türkiye Bankalar Birliği, 2002) nedeniyle USDTRY kuru ile borsa endeksi arasındaki ilişkinin bu dönemde incelenmesi sağlıklı olmayacaktır. Fakat yine de her ne kadar 2001 yılına kadar sabit kur rejimi kullanılmış olsa da kriz dönemlerinde devalüasyona gidilmek zorunda kalındığı ve kurda ciddi hareketlerin olduğu görülmektedir. Bu yüzden çalışmada USDTRY kuru ile BIST100 endeksi arasındaki ilişkiler kriz dönemleri ile 2001 ile 2020 yılları arasındaki uzun vadeli olmak üzere ayrı ayrı incelenmiştir.

Türkiye'de 1990'lardan bu yana USDTRY kurunun gelişimi incelendiğinde, bu gelişimi üç farklı döneme bölmek mümkün olacaktır (Bkz. Şekil 1). Sabit kurun uygulandığı, çift haneli yüksek enflasyonun yaşandığı birinci dönem 2001 yılına kadar sürmüştür. Bu dönemde dolar kurunun reelde Türk lirasına karşı hafif eğimli olarak değer kaybettiği fakat kriz dönemlerinde ani sıçramalar yaşandığı görülmektedir. 2001 sonrası ise IMF programının yürürlüğe girmesi ve gerçekleştirilen bir dizi yapısal reformlar sonrası (Turgut, 2006:10) enflasyon oranı düşmüş ve 2013 yılına kadar bu performans sürdürülmüştür. 2013 yılından sonra ise TCMB'nin daha genişleyici para politikası uyguladığı (Sümer, 2020) ve döviz kurlarının ise arttığı görülmektedir.

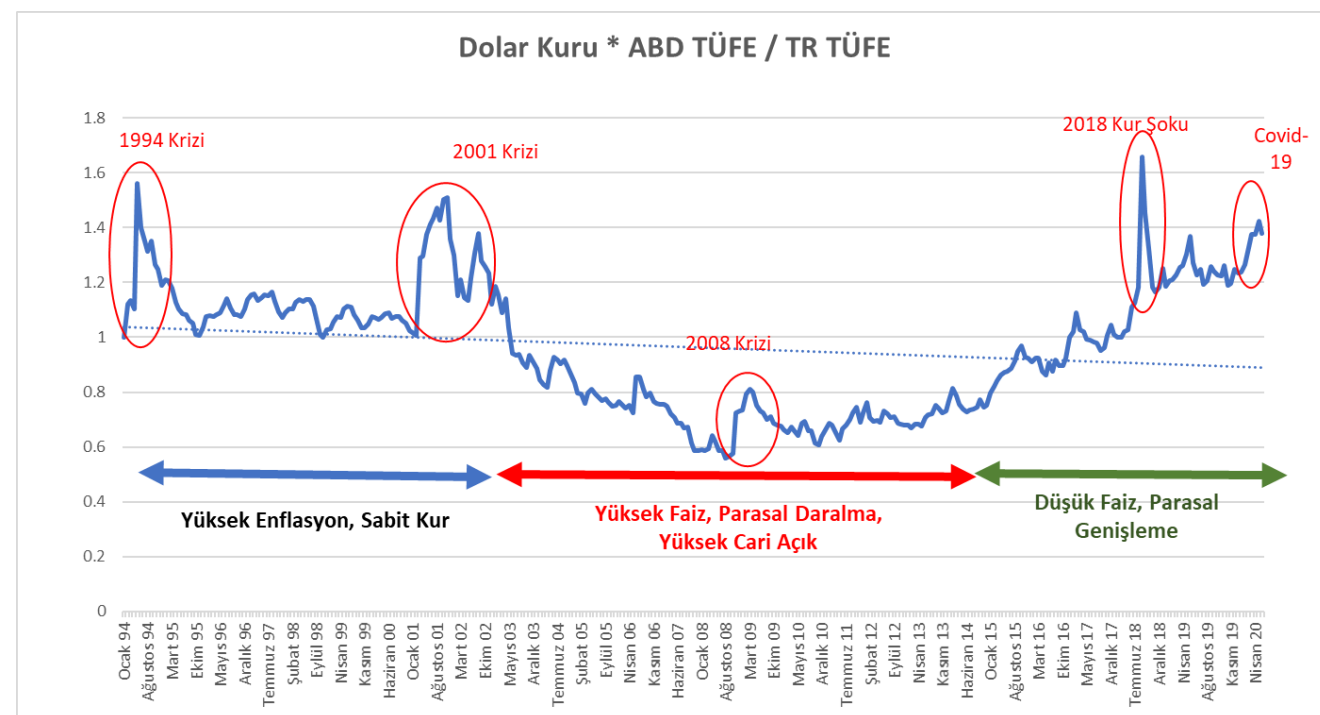




\section{Şekil 1. ABD ve Türkiye'deki TÜFE Oranları Kullanılarak Enflasyon Etkisinden Arındırılmış Olan USDTRY Kurunun Gelişimi}

Kaynak: TUIK, investing.com ve TCMB verileri kullanılarak yazar tarafindan oluşturulmuştur.

Literatürdeki çalışmalar incelendiğinde Tablo 1'de belirtilmiş olan bütün çalışmalarda borsa endeks verisinde enflasyon düzenlemesi yapılmadığı görülmektedir. Diğer yandan döviz kurlarında da genellikle nominal değerler kullanıldığı, az sayıda çalışmada ise reel kur değerleri alındığı görülmektedir (Belen ve Karamelekli, 2016; Boyacığlu ve Çürük, 2016; Emsen, Sadeghzadeh ve Aksu, 2019; Türsoy, 2017). Türkiye yıllardır yüksek tek haneli ya da çift haneli enflasyonun yaşandığı bir ülkedir. Enflasyon hem döviz kurlarına hem de borsa endeksine pozitif etkisi olan bir etmendir. Türk borsasında işlem gören şirketlerin çoğunluğunun satış değerleri doğrudan Türkiye'deki enflasyon ile ilişkilidir. Bu da haliyle şirketlerin net karlarını ve değerlemelerini etkilemektedir. Enflasyonun yani Türk lirasının alım gücündeki düşüşün uzun vadede hem dolar kurunu hem de borsa endeksini yukarı yönlü olarak etkilemesi nedeniyle literatürdeki enflasyonu dikkate almamış birçok çalışmada uzun vadeli ilişkiler sağlıklı hesaplanamamıştır. Birçok çalışma USDTRY kuru ve borsa endeksi arasında pozitif ilişki olduğunu belirtmiş olsa da bunun asıl nedeni döviz kurları ve enflasyon arasındaki ilişkiden değil ülkedeki enflasyondan kaynaklanmaktadır. Burada USDTRY kuru ile enflasyonun birbirini etkilediği tartışması sunulabilir. Fakat döviz kurlarının enflasyondan çok daha oynak olduğu ve ayrıca Şekil 1'de görüleceği üzere dönemsel olarak döviz kurları ile enflasyon arasında büyük ölçekli farklılaşmalar olduğu gözden kaçmamalıdır. Ayrıca yatırımcı açısından düşünüldüğünde, yüksek enflasyonun olduğu bir ülkede nominal kazanç önemini kaybedebilir ve reel kazancın ön plana çıkacağı düşünülebilir. $\mathrm{Bu}$ nedenle bu çalışmada döviz kurlarının reel bir hedge mekanizması olarak borsa yatırımcıları tarafından ne kadar etkin kullanılabileceği sorusuna cevap aranmış ve yapılan analizlerde reel getiriler kullanılmıştır. Yabancı yatırımcılar için varlıklarının döviz cinsinden değeri önemli olduğu için doğal olarak hedge işlemine ihtiyaç duymaktadırlar, fakat bu çalışmada daha çok Türk yatırımcılar için bilgi sunulmaya çalışılmıştır.

Araştırma sorusu: Dolar, Borsa İstanbul'a yatırım yapan yatırımcılar için hedge mekanizması olarak kullanılabilir mi?

Araştırma metodolojisi üç aşamada kurgulanmıştır. İlk aşamada serbest kur rejiminin uygulandığı 2001 ile 2020 yılları arasındaki reel USDTRY kurunun ve reel BIST100 endeksinin aylık performansları arasındaki ilişki regresyon analizi ile test edilmiştir. Regresyon analizi yapılmadan önce Augmented Dickey-Fuller (Said and Dickey, 1984) testi ile değişkenlerin durağanlığı sınanmış ve en küçük kareler yönteminin uygulanmasına uygun olup olmadığı anlaşılmıştır. Daha sonrasında aşağıdaki 1 nolu denklem vasıtasıyla regresyon analizi yapılmıştır. Bu denklemde RBIST100 $\mathrm{t}$ ayındaki enflasyondan etkisinden arındırılmış BIST100 endeksinin getirisini, RUSDTRY $\mathrm{t}_{\mathrm{t}}$ ayındaki enflasyon etkisinden arındırılmış USDTRY kurunun değişimini ifade etmektedir. Yatırımcılar açısından uzun vadeli getirilerin önemli olması ve günlük fiyat hareketlerinin birçok farklı etkenden etkilenmesi nedeniyle ilişkilerin daha sağlıklı ölçülebilmesi için aylık frekans seçilmiştir.

$R B I S T 100_{t}=\alpha_{0}+\beta_{1} \operatorname{RUSDTR} Y_{t}+\varepsilon_{\mathrm{t}}$

İkinci aşamada 2001 ve 2008 yıllarındaki ekonomik krizler ve 2018 yılında yaşanan kur şoku sırasında reel BIST100 endeksi ile reel USDTRY kuru arasındaki ilişki incelenmiştir. Kriz 
dönemlerinde piyasanın çok daha hızlı hareket etmesi nedeniyle aylık yerine haftalık frekans seçilmiştir. Regresyon analizinde haftalık değerler kullanılması dışında denklem 1'e bağlı kalınmıştır.

Üçüncü aşamada, Tsai'nin (2012) Asya ülkelerinde döviz kuru ile borsa endeksleri arasındaki ilişkiyi incelediği çalışmaya benzer şekilde yüzdelik regresyon yaklaşımı uygulanmıştır. Bu amaçla 2001 ve 2020 yılları arasındaki aylık reel USDTRY kuru getirileri yüksekten düşüğe göre sıralanmıştır. Reel USDTRY kurunun en çok düştüğü \%30'luk dilime düşen aylar 1 . yüzdelik dilimi; reel USDTRY kurunun ortalama performans gösterdiği \%40'lık dilim içindeki aylar 2. yüzdelik dilimi ve son olarak reel USDTRY kurunun en yüksek performans gösterdiği aylar ise 3. yüzdelik dilimi oluşturmuştur. Daha sonrasında bu yüzdelik dilimler baz alınarak regresyon analizleri gerçekleştirilmiş ve sonuçlar sunulmuştur.

\section{BULGULAR}

Reel USDTRY kuruna ve enflasyondan etkisinden arındırılmış BIST100 endeksine ait tanımlayıcı istatistikler Tablo 2'de sunulmuştur.

Tablo 2. Tanımlayıcı İstatistikler

\begin{tabular}{lll}
\hline & RXU100 & RUSDTRY \\
\hline Ortalama & $0,42 \%$ & $0,26 \%$ \\
\hline Medyan & $0,88 \%$ & $-0,35 \%$ \\
\hline Maksimum & $39,71 \%$ & $31,07 \%$ \\
\hline Minimum & $-27,10 \%$ & $-11,50 \%$ \\
\hline Standart Sapma & 0,093 & 0,051 \\
\hline Barpıklık & 0,219 & 1,772 \\
\hline Olasılık & 4,417 & 12,057 \\
\hline Gözlem Sayısı & 0,000 & 0,000 \\
\hline
\end{tabular}

Borsa'da hisse senetlerine yatırım yapan yatırımcıların risklerinin en çok arttığı dönemler ekonomik krizlerdir. Yatırımcıların döviz yatırımlarıyla bu riskten ne ölçüde korunabileceği analiz edilebilir. Şekil 2'de reel USDTRY kuru ve reel BIST100 endeksinin son yıllardaki gelişimi verilmiştir. Grafiğe bakıldığında ilk dikkat çeken durum krizler ile reel USDTRY kurundaki artış arasında yakın bir ilişki olduğudur. Grafiğge bakıldığında ulaşılan bir diğer gözlem ise reel BIST100 endeksinin her kriz döneminde ciddi düşüşler yaşamasıdır. Bir diğer gözlem ise Türkiye'de enflasyonun kontrol alınması için yüksek reel faiz ve mali disiplinin uygulandığı 2001 ve 2008 yılları arasındaki dönemde reel USDTRY kurunun sürekli düşmesi ve yine aynı dönemde BIST100 endeksinin yükselmesidir. 


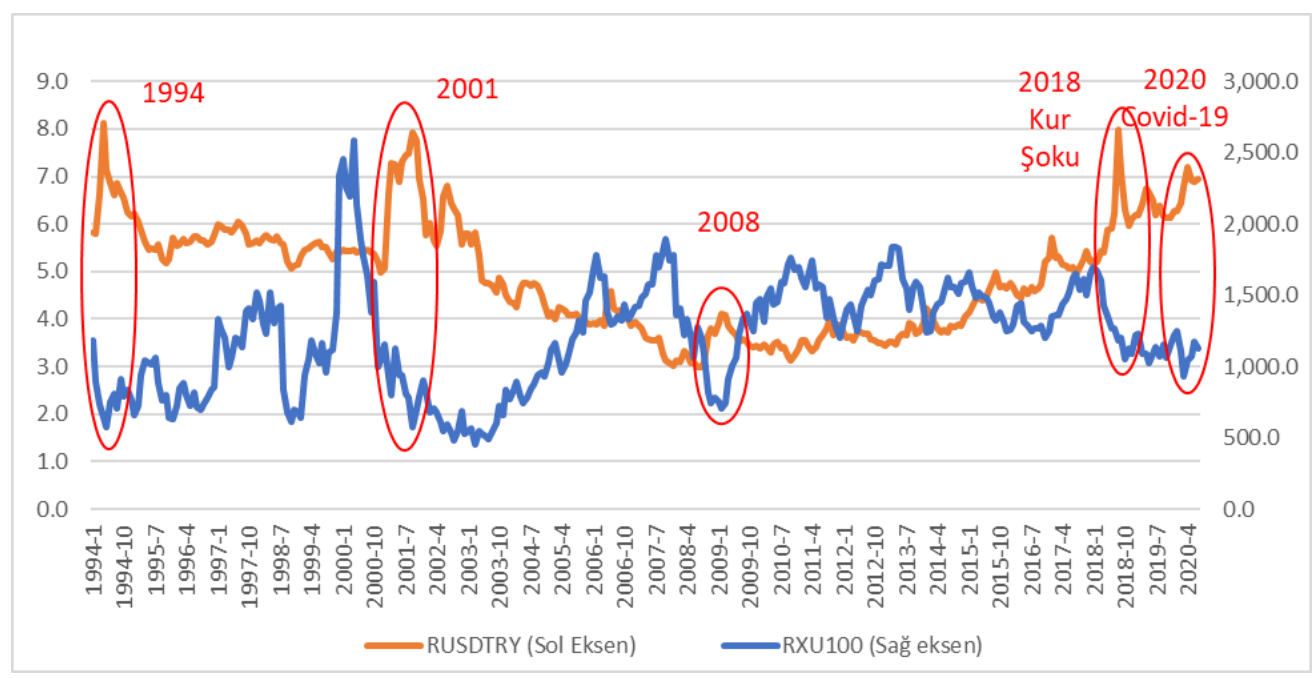

Şekil 2. Reel USDTRY ve Reel BIST100 Endeksinin Kriz Dönemlerindeki Gelişimi

$\mathrm{Bu}$ ilişkinin istatistiksel olarak ne derecede anlamlı olduğunun anlaşılması için öncelikle reel USDTRY kuru ve reel BIST100 endeksi için Augmented Dickey-Fuller birim kök testleri yapılmıştır. Her iki değişkenin düzeyde I(0) durağan olmadıkları fakat birinci farkta I(1) durağan oldukları tespit edilmiştir (Bkz. Tablo 3). Değişkenlerin düzeyde durağan olmaması nedeniyle Johansen (1991) tarafından önerilen eş bütünleşme testi uygulanmıştır. Elde edilen sonuçlara göre seriler arasında, aylık değişim oranları analiz edildiğinde, eşbütünleşme olmadığ1 saptanmıştır (Bkz. Tablo 4). Değişkenler arasında uzun vadeli bir ilişki olmaması söz konusu olsa da özellikle hedge amaçlı kullanımlarda kısa vadeli ilişki olması önemlidir. Ayrıca değişkenlerin aynı seviyede durağan olması nedeniyle en küçük kareler yöntemi ile regresyon yapılması uygun olacaktır. Bu yüzden Tsai’nin (2012:614) de izlediği yol kullanılarak ve durağanlığı tespit edilmiş olan reel BIST100 endeksi ve reel USDTRY kurlarındaki değişim verisi ile en küçük kareler yöntemiyle regresyon analizi yapılmıştır.

Tablo 3. Augmented Dickey-Fuller Olasılık Değerleri

\begin{tabular}{|c|c|c|c|c|c|c|c|c|}
\hline & \multicolumn{4}{|c|}{ RUSDTRY } & \multicolumn{4}{|c|}{ RBIST100 } \\
\hline & \multicolumn{2}{|c|}{ Sabitli } & \multicolumn{2}{|c|}{ Sabitli ve Trendli } & \multicolumn{2}{|c|}{ Sabitli } & \multicolumn{2}{|c|}{ Sabitli ve Trendli } \\
\hline & $\mathrm{t}$ ist. & Olasılık & $\mathrm{t}$ ist. & Olasılık & $\mathrm{t}$ ist. & Olasilik & $\mathrm{t}$ ist. & Olasilik \\
\hline $\mathrm{I}(0)$ & -1.20 & 0.68 & -1.29 & 0.89 & -2.28 & 0.18 & -2.48 & 0.34 \\
\hline $\mathrm{I}(1)$ & -14.57 & 0.00 & -12.63 & 0.00 & -16.46 & 0.00 & -16.43 & 0.00 \\
\hline
\end{tabular}

Tablo 4. Johansen Eş Bütünleşme Testi Sonuçları

Test edilen

hipotezlere ait eş

bütünleşme sayısı

Eigen Değeri ～İz İstatistiği $\quad 0,05$ Kritik Değeri $\quad$ Olasılık

\begin{tabular}{ccccc}
\hline Yok & 0.033882 & 3.443993 & 12.32090 & 0.7893 \\
\hline En Fazla 1 & 0.000673 & 0.066002 & 4.129906 & 0.8331 \\
\hline
\end{tabular}


Türkiye'nin değişken döviz kuruna geçtiği tarih olan 2001 Ocak ayından başlanarak 2020 Temmuz ayına kadarki dönemde aylık frekansta reel USDTRY kuru ve reel BIST100 endeksi arasındaki ilişkinin test edildiği regresyon analizi sonuçları Tablo 5'te sunulmuştur. RBIST100, BIST100 endeksinin aylık reel getirisini, RUSDTRY ise USDTRY kurunun aylık reel değişimini göstermektedir. Durbin Watson istatistiğinin $n>200$ ve $k=1$ için 2,29'dan küçük bir değer olması nedeniyle denklemde otokorelasyonun olmadığı görülmektedir. İki farklı değişken arasındaki ilişkinin istatistiksel olarak anlamlı olduğu ve kat sayının -0.802 düzeyinde olduğu dikkat çekmektedir. $\mathrm{R}^{2}$ değerinin ise yalnızca 0,19 olduğu tespit edilmiştir. Hedge mekanizmalarına kriz dönemlerinde daha fazla ihtiyaç duyulmaktadır. Yatırımcıların normal dönemlerde de belirli bir volatiliteye maruz kalması söz konusu olabilir. Reel USDTRY kurunun kriz dönemlerinde BIST100 için hedge özelliği taşıyıp taşımadığı devam eden bölümlerde incelenecektir.

Tablo 5. 2001-2020 Yılları Arasındaki Regresyon Analizi Sonuçları

$\operatorname{RBIST100}{ }_{t}=\alpha_{0}+\beta_{1} \operatorname{RUSDTRY}_{t}+\varepsilon_{t}$

\begin{tabular}{lcccc}
\hline Değişken & Katsayı & $\begin{array}{c}\text { Standart } \\
\text { Sapma }\end{array}$ & t istatistiği & Olasıllk \\
\hline RUSDTRY & -0.802 & 0.107 & -7.465 & 0.000 \\
\hline C & 0.006 & 0.005 & 1.142 & 0.255 \\
\hline Ayarlanmış R ${ }^{2}$ & 0.190 & & Durbin-Watson İstatistiği & 2.191 \\
\hline
\end{tabular}

Türkiye'de BİST100 endeksinin son 20 yılda yüksek ölçekte düştüğü dönemlere ait regresyon analizi sonuçları Tablo 6'da gösterilmiştir. Haftalık frekansta yapılan analizde BİST100 endeksinin düşmeye başladığı ve sonrasında yaşanan tepki hareketi sonucu yataya döndüğü tarihe kadarki dönemler dikkate alınmıştır. 1994 ekonomik krizi o dönemde sabit kur politikasının uygulanması nedeniyle analiz edilmemiştir. Elde edilen sonuçlara göre olasılık değerlerine bakıldığında yalnızca 2008 krizinde istatistiksel olarak anlamlı bir ilişki söz konusudur. 2008 krizinde reel USDTRY ve reel BIST100 endeksi arasında -0,89 gibi yüksek derecede negatif yönlü korelasyon söz konusudur; fakat düzeltilmiş $\mathrm{R}^{2}$ değerleri 0,23 'tür. Elde edilen bulgulara göre reel USDTRY BIST100 endeksine karşı anlık bir hedge etkisi oluşturmamaktadır.

Tablo 6. Ekonomik Kriz ve Döviz Şoku Dönemlerindeki Regresyon Analizi Sonuçları RBIST100 ${ }_{t}=\alpha_{0}+\beta_{1}$ RUSDTRY $+\varepsilon_{t}$

\begin{tabular}{lccc}
\hline Dönem & $\mathbf{2 0 0 1}$ & $\mathbf{2 0 0 8}$ & $\mathbf{2 0 1 8}$ \\
\hline Başlangıç & 25.04 .2000 & 31.12 .2007 & 26.02 .2018 \\
\hline Bitiş & 9.04 .2002 & 28.12 .2009 & 28.01 .2019 \\
\hline Katsayı & -0.220 & $\mathbf{0 . 8 8 7}$ & -0.054 \\
\hline Standart Sapma & 0.145 & 0.159 & 0.089 \\
\hline t istatistiği & -1.520 & -5.584 & -0.607 \\
\hline Olasılık & 0.132 & $\mathbf{0 . 0 0 0}$ & 0.547 \\
\hline Ayarlanmış $\mathbf{R}^{\mathbf{2}}$ & 0.013 & 0.232 & 0.014 \\
\hline Durbin Watson & 1.882 & 2.121 & 2.034 \\
\hline
\end{tabular}

Her ne kadar reel USDTRY ve reel BIST100 endeksi arasında kusursuz ve eş zamanlı çalışan bir negatif yönlü ilişki bulunmamış olsa da yine de uzun vadeli modelde istatistiksel olarak 
$\% 0,1$ anlamlılık düzeyinde elde edilmiş olan negatif ilişki, analizin daha da detaylandırılmasını gerekli kılmıştır. Bu aşamada Şekil 3 'te kriz dönemlerinde reel USDTRY ve reel BIST100 endeksi ilişkisi gösterilmiştir. Reel USDTRY kuru ile reel BIST100 endeksi arasındaki ilişkinin daha net anlaşılabilmesi için dikey eksendeki reel USDTRY kuru değerleri ters sırada sunulmuştur. Dört farklı dönemde de reel BIST100 endeksinin önceden düşmeye başladığı fakat sonrasında bu düşüşe reel USDTRY kurunun da eşlik ettiği görülmektedir.

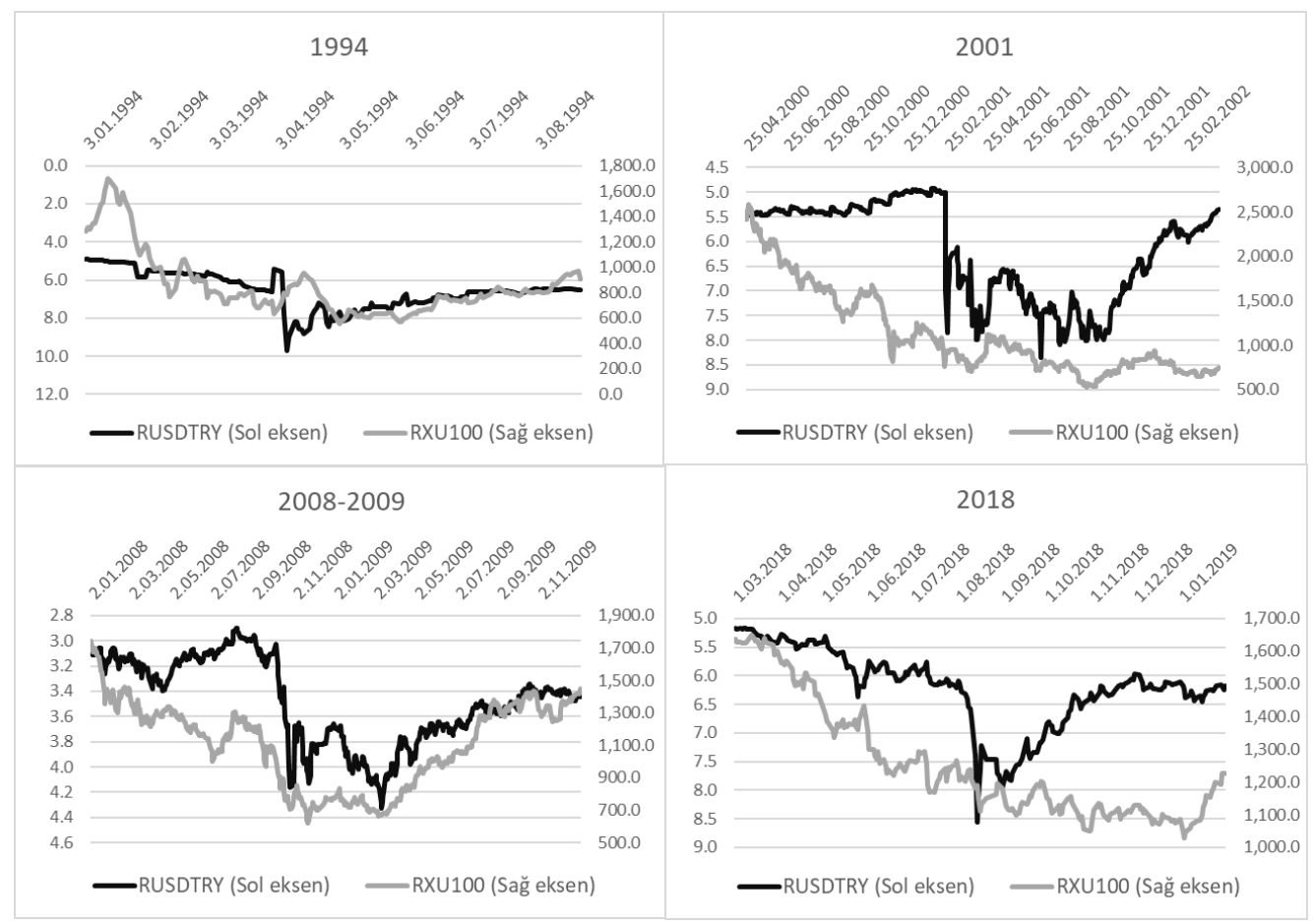

Şekil 3. Reel USDTRY ve Reel BIST100 Endeksinin Kriz Dönemlerindeki Gelişimi

İki farklı değişken arasındaki ilişki incelenirken özellikle hedge amaçlı yapılan testlerde, aradaki ilişkinin belli dönemlerde çalışması daha önemlidir. $\mathrm{Bu}$ aşamada Tsai'nin (2012) kullandığg yöntem ile reel USDTRY'nin sert bir şekilde yükseldiği ya da düştüğü dönemlerde reel BIST100 endeksi ile reel USDTRY kuru arasındaki ilişkinin nasıl gerçekleştiği analiz edilmiştir. Bunun için 2001 ile 2020 yılları arasındaki dönemde aylık reel USDTRY kuru değişimleri küçükten büyüğe doğru sıralanmıştır. Reel USDTRY kurunun en düşük performans gösterdiği \%30'luk dilime giren aylar 1. modele; sonraki \%40'lık dilime giren aylar model 2'ye ve reel USDTRY kurunun en yüksek performans gösterdiği \%30'luk dilime giren aylar ise model 3'e dahil edilmiştir. Sonuçlar Tablo 7'de sunulmuştur. Elde edilen bulgulara göre istatistiksel olarak $\% 5$ düzeyinde anlamlı ilişki yalnızca reel USDTRY'nin yüksek performans gösterdiği aylarda (Panel 3) söz konusudur ve reel USDTRY kuru ile reel BIST100 endeksi arasında negatif yönlü ilişki bulunmaktadır. 
Tablo 7. 2001 ve 2020 Yılları Arasındaki Reel USDTRY Kurunun Aylık Getirisine Göre Derecelendirilmiş Yüzdelik Dilimlere Bağlı Olarak Hazırlanmış Regresyon Analizi Sonuçları $\operatorname{RBIST100}_{t}=\alpha_{0}+\beta_{1} \operatorname{RUSDTRY}_{t}+\varepsilon_{t}$

\begin{tabular}{|c|c|c|c|}
\hline Yüzdelik Dilim & $\begin{array}{c}\mathbf{1} \\
\text { (En Düşük Reel } \\
\text { USD Performans1) }\end{array}$ & 2 & $\begin{array}{c}\mathbf{3} \\
\text { (En Yüksek Reel } \\
\text { USD Performansı) }\end{array}$ \\
\hline Katsayı & -0.045 & -1.169 & -0.434 \\
\hline Standart Sapma & 0.427 & 0.663 & 0.200 \\
\hline $\mathrm{t}$ istatistiği & -0.106 & -1.763 & -2.170 \\
\hline Olasılık & 0.916 & 0.081 & 0.034 \\
\hline Ayarlanmış R2 & -0.015 & 0.022 & 0.051 \\
\hline Durbin Watson & 1.867 & 2.373 & 1.964 \\
\hline
\end{tabular}

\section{SONUÇ}

$\mathrm{Bu}$ çalışmada Borsa İstanbul'da yatırım yapan yatırımcılar için doların hedge amaçlı kullanımının ne kadar etkin olduğu araştırılmıştır. 1994 yılından 2020 yılına kadar ki dönemin dahil edildiği araştırmada üç aşamada analiz yapılmıştır. Gerek USDTRY kuru gerekse BIST100 performansı üzerinde enflasyonun etkisinin yüksek olması nedeniyle, reel USDTRY kuru ve reel BİST100 endeksi kullanılarak analizler gerçekleştirilmiştir. Bu sayede yatırımcılar açısından da önem arz eden reel getiri unsurunun dikkate alınması mümkün olmuştur. Araştırmada ilk olarak ABD'deki enflasyon ve TÜFE etkisinden arındırılmış USDTRY kurunun 1994 ve 2020 yılları arasındaki performansı incelenmiştir. 1990'larda Türkiye'de yüksek enflasyon söz konusudur ve 2001 yılına kadar sabit kur uygulanmıştır. Bu zaman diliminde reel USDTRY kurunun aşağı yönlü hareket ettiği gözlemlenmekte yalnızca kriz dönemlerinde bu durumun tersinin söz konusu olduğu ve ani yükseliş ve tekrar geri dönüşlerin gerçekleştiği tespit edilmiştir. 2001 ve 2008 arasındaki dönemde ise Türkiye'de s1kı maliye ve para politikaları hakimdir (Kantarcı ve Karacan, 2008). Bu y1llarda ise doların reel değerinin düştüğü gözlemlenmektedir. 2008 sonrası dönemde tekrar esnek para politikasına geçilmiş ve dolar 2020'ye kadar geçen dönemde düzenli olarak enflasyonun üstünde yükselmiştir. Yine bu dönemde 2018 kur şoku düzenli gerçekleşen eğimde bir istisnayı oluşturmuştur. USDTRY kurunun farklı yıllardaki ve farklı dönemlerdeki hareket şeklinin değişiklik göstermesi bu dönemlerin hepsini kapsayacak bir çalışmanın önemini artırmıştır.

Bu amaçla ilk olarak dalgalı kur sisteminin uygulandığı 2001 ve 2020 yılları arasında aylık frekansta reel USDTRY kuru ile reel BIST100 endeksi arasındaki ilişki regresyon analizi ile test edilmiştir. Elde edilen sonuçlara göre bu ikili arasında güçlü bir ters korelasyon bulunmaktadır. Bu regresyon analizinde reel USDTRY kuru ve reel BİST100 endeksinin kullanılmış olması, çalışmayı literatürdeki diğer çalışmalardan ayrıştırmaktadır. $\mathrm{Bu}$ çalışmanın aksine literatürdeki birçok araştırmada USDTRY kuru ve BİST100 endeksi arasında pozitif ilişki olduğu raporlanmıştır (Alacahan ve Akarsu, 2019; Boyacıoğlu ve Çürük, 2016; Hersi ve Koy, 2020; Kayral, 2020). Bu çalışmaların hiçbirinde enflasyondan arındırılmış BIST100 endeksinin kullanılmaması nedeniyle ilişkinin pozitif çıkması normal bir sonuç oluşturmaktadır. Çünkü Türkiye'deki yüksek enflasyon hem doları hem de 
BİST100 endeksini yukarı taşımaktadır. Fakat yatırımcı açısından baktığımızda enflasyondan arındırılmış değerler daha önemlidir.

Araştırmanın ikinci aşamasında 2001, 2008 ve 2018 ekonomik kriz dönemlerinde aynı ilişki haftalık frekansta test edilmiştir. Buradan elde edilen sonuçlara göre reel USDTRY kuru ile reel BIST100 endeksi arasında istatistiksel olarak anlamlı ilişki yalnızca 2008 krizinde mevcuttur. Fakat reel BİST100 endeksi ile reel USDTRY kurunun birlikte gösterildiği 1994, 2001, 2008 ve 2018 krizlerini içeren grafiklere bakıldığında hepsinin ortak özelliğinin BİST100 endeksinde ciddi düşüş, reel USDTRY kurunda ise ciddi yükseliş olduğu dikkat çekmektedir. Diğer yandan bütün krizlerde BİST100 endeksi önceden düşmüş, USDTRY kuru hareketi ise sonradan söz konusu olmuştur. Bu durum, merkez bankasının ve kamunun işlemlerinin USDTRY kuru üzerindeki etkisinin yüksek oluşu; BİST100 endeksinde ise büyük ölçüde serbest piyasa şartlarının geçerli olması ile açıklanabilir. USDTRY kuru bütün krizlerin başlangıç dönemlerinde kontrol altında tutulmuş fakat kriz daha belirgin hale gelince ani bir hareketle ciddi anlamda yükselmiştir. Buradan elde edilen sonuçlar doların özellikle kriz dönemlerinde etkin bir hedge işlevi üstlendiğini göstermektedir.

Araştırmanın üçüncü aşamasında ise reel USDTRY kurunun yüksek, normal ve düşük performans gösterdiği aylar ayıklanarak oluşturulan modellerde reel USDTRY kuru ile reel BIST100 endeksi arasındaki ilişki incelenmiştir. Elde edilen sonuçlar reel USDTRY kuru ile reel BIST100 endeksi arasındaki negatif ilişkinin yalnızca reel USDTRY kurunun yükseldiği zamanlarda geçerli olduğunu göstermektedir. USDTRY kuru ve BIST100 endeksine etki eden birçok etmen vardır. Örneğin ani olarak sıkılaştırılan para politikasının USDTRY kurunu düşürebilmesi söz konusu olabilir ve borsadaki şirketleri ise artan finansman maliyetleri nedeniyle sarsabilir. Esnek para politikasının ise artan likidite nedeniyle hem USDTRY kurunda hem de BIST100 endeksi üzerinde pozitif etki oluşturabilir. Diğer yandan FED'in faiz politikasındaki artış, USD likiditesini sınırlayarak USDTRY kurunda artış etkisi oluşturabilir. Nispeten BIST100 üzerindeki etkisinin ise daha sınırlı olması söz konusu olabilir. Borsada birçok şirket bulunmakta, bu şirketlerin USDTRY kurundan bağımsız olarak işleri iyi ya da kötü gidebilmektedir. Bu da haliyle endeksin USDTRY kurundan bağımsız olarak da hareket etmesine yol açabilmektedir. $\mathrm{Bu}$ nedenle normal şartlar altında bu ikili arasındaki ilişkinin kuvvetli olmaması ve değişkenlik göstermesi normal karşılanabilir. Fakat kriz dönemlerinde çok sert hareketler ortaya çıkmakta, yabancı portföy çıkışları hem USDTRY kurunu yukarı çekmekte hem de BIST100 endeksini düşürmektedir. Bu araştırma sonuçlarına göre bu dönemlerdeki hareketlerin çok güçlü olması diğer dinamiklerin arka planda kalmasına yol açmakta ve reel USDTRY kuru ile reel BIST100 endeksi arasında ortaya istatistiksel olarak anlamlı ve ters yönlü bir ilişki çıkarmaktadır.

Borsa yatırımcıları açısından düşünüldüğünde yaşanabilecek önemli risklerden ikisi şu şekilde sıralanabilir. (1) Yatırım yaptıkları firmaların çoğunluğunun işlerinin kalıcı olarak bozulması ya da iflas etmesi. (2) Türk lirasının önemli bir devalüasyona uğraması ve piyasadaki risk algısının bozulması sonucu uğrayacakları kayıplar. Her iki riskin gerçekleşmesi durumu oluştuğunda USDTRY kurunun da Türk lirasına karşı ciddi anlamda değer kazanması söz konusu olacaktır. Bu nedenle borsa yatırımcıları için USDTRY kurunun uygun bir hedge mekanizması olduğu düşünülmektedir. Yatırımcılar bu hedge mekanizmasından portföylerinin belli bir bölümünü dolara yatırarak faydalanabilecekleri gibi ayrıca VIOP kontratlarını da kullanabilirler. 
Konuyla ilgili bundan sonra yapılacak araştırmalarda sektör bazlı olarak döviz kurları ve hisse fiyatları arasındaki ilişki incelenebilir. Ayrıca değişik makro ekonomik değişkenlerin dahil edildiği çalışmalarda hangi makro dinamiklerin bu ilişki de etkili olduğu tespit edilebilir.

\section{KAYNAKÇA}

ABHYANKAR, H. (2020). "Assessing the Positivity of Negative Interests Rates with Reference to the Euro-Area". The Arthniti, 1(1), 58-64.

AGRAWAL, G., SRIVASTAV, A. K., \& SRIVASTAVA, A. (2010). "A Study of Exchange Rates Movement and Stock Market Volatility". International Journal of Business and Management, 5(12), 62.

AKKAS, M. E. (2016). "Finansal Olmayan Şirketlerde Döviz Kuru Etkisinin Sermaye Piyasası Yaklaşımına Göre Ölçülmesine Yönelik Bir Literatür Taraması”. Business and Economics Research Journal, 7(1), 71-87.

AKINCI, G. Y., \& KÜÇÜKÇAYLI, F. (2016). "Hisse Senedi Piyasası ve Döviz Kuru Mekanizmaları Üzerine Bir Panel Veri Analizi”. Muhasebe ve Finansman Dergisi, (71), 127-148.

ALACAHAN, N. D., \& AKARSU, Y. (2019). “Döviz Kuru Riskinin Borsa İstanbul 100 Endeksi Üzerindeki Etkisi Zaman Serisi Analizi: Türkiye Örneği”. Journal of Life Economics, 6(2), 133-150.

AYDEMIR, O., \& DEMIRHAN, E. (2009). "The Relationship Between Stock Prices and Exchange Rates: Evidence from Turkey". International research journal of finance and economics, 23(2), 207-215.

AYDIN, M. (2017). “Gelişmekte Olan Ülkelerde Borsa ile Döviz Kurları Arasındaki İlişki: Simetrik ve Asimetrik Nedensellik Analizi”. Ekonometri ve Istatistik Dergisi, (27), 1 15 .

AYVAZ, Ö. (2006). "Döviz Kuru ve Hisse Senetleri Fiyatları Arasındaki Nedensellik İlişkisi”. Gazi Üniversitesi İktisadi ve İdari Bilimler Fakültesi Dergisi 8 / 2 (2006). 1 14

BDDK, Bankacılık Düzenleme ve Denetleme Kurumu. (2020). “Aylık Bankacılık Sektörü Verileri (Temel Gösterim)", https://www.bddk.org.tr/BultenAylik

BELEN, M., \& KARAMELİKLİ, H. (2016). “Türkiye'de Hisse Senedi Getirileri ile Döviz Kuru Arasındaki İlişkinin İncelenmesi: ARDL Yaklaşımı”. Istanbul University Journal of the School of Business Administration, 45(1).

BLOOMBERGHT. (2020). "BİST'te en büyük portföye sahip yabancı yatırımcılar ABD Katar ve İngiltere”, https://www.bloomberght.com/bist-te-en-buyuk-portfoye-sahipyabanci-yatirimcilar-abd-katar-ve-ingiltere-2248394

BOYACIOĞLU, M. A., \& ÇÜRÜK, D. (2016). "Döviz Kuru Değişimlerinin Hisse Senedi Getirisine Etkisi: Borsa İstanbul 100 Endeksi Üzerine Bir Uygulama”, Muhasebe ve Finansman Dergisi, (70), 143-156. 
ÇEVİK, F., \& ÇANKAYA, S. (2020). “Gelişmekte Olan Ülkelerde Borsa Getirileri, Net Yabancı Alımları ve Döviz Kurları Arasındaki İlişki”. Bankacılık ve Sermaye Piyasası Araştırmaları Dergisi, 4(9), 23-43.

DEMİRALE, Ö. (2020). "Mutual Interaction Analysis Between Stock Market Index and Financial Indicators By Granger Causality Method”. Florya Chronicles of Political Economy, 6(1), 1-13.

DIMITROVA, D. (2005). "The relationship between exchange rates and stock prices: Studied in a multivariate model". Issues in Political Economy, 14(1), 3-9.

DOĞUKANLI, H., ÖZMEN, M., \& YÜCEL, E. (2010). “İMKB'DE Sektörel Açıdan Döviz Kuru Duyarlılığının İncelenmesi”. Journal of the Cukurova University Institute of Social Sciences, 19(3).

EMSEN, Ö. S.; SADEGHZADEH, K.; \& AKSU, H. (2019). "İran Borsası ve Reel Döviz Kuru Arasındaki Simetrik ve Asimetrik İlişkilerinin İncelenmesi”. Cumhuriyet Üniversitesi İktisadi ve İdari Bilimler Dergisi, 20(1), 181-192.

EYÜBOĞLU, S., \& EYÜBOĞLU, K. (2018). "Borsa İstanbul sektör endeksleri ile döviz kurları arasındaki ilişkilerin incelenmesi: ARDL modeli”. Academic Review of Economics \& Administrative Sciences, 11(1).

GRANGER, C. W., HUANGB, B. N., \& YANG, C. W. (2000). “A bivariate causality between stock prices and exchange rates: evidence from recent Asianflu". The Quarterly Review of Economics and Finance, 40(3), 337-354.

HATEMI-J, A., \& IRANDOUST, M. (2002). “On the Causality Between Exchange Rates and Stock Prices: A note”. Bulletin of Economic Research, 54(2), 197-203.

HERSI, K. Y., \& KOY, A. (2020). “The Relationship between Exchange Rates and Stock Markets for the Fragile Five Countries". Journal of International Trade, Logistics and Law, 6(1), 1.

İLARSLAN, K. (2018). "Kısa ve Uzun Dönemde Döviz Kurları ile Borsa Endeksi Arasındaki İlişkinin Açıklanmasına Yönelik Ampirik Bir Çalışma”. Hacettepe University Journal of Economics \& Administrative Sciences/Hacettepe Üniversitesi Iktisadi ve Idari Bilimler Fakültesi Dergisi, 36(1).

JOHANSEN, S. (1991). "Estimation and Hypothesis Testing of Cointegration Vectors in Gaussian Vector Autoregressive Models". Econometrica: journal of the Econometric Society, 1551-1580.

İNCİ, A. C., \& LEE, B. S. (2014). "Dynamic Relations Between Stock Returns and Exchange Rate Changes". European Financial Management, 20(1), 71-106.

İ̧CAN, E. (2011). “Döviz Kurları ve Hisse Senedi Piyasası Arasındaki Etkileşim”. Elektronik Sosyal Bilimler Dergisi, 10(35), 237-251.

KANTARCI, H. B., \& KARACAN, R. (2008). "Mali disiplinin sağlanması açısından Türkiye IMF ilişkilerinin değerlendirilmesi”. Maliye Dergisi, 155, 144-158. 
KARABIYIK, C., \& ÇILBANT, C. (2020). “Gelişen Piyasa Ekonomilerinde Konjonktür Karşıtı Para Politikası”. Ege Stratejik Araştırmalar Dergisi, 11(1), 1-20.

KARAMUSTAFA, O., \& KÜÇÜKKALE, Y. (2002). “Türkiye'de Kriz Döneminde KurFaiz-Borsa İlişkilerinin Dinamik Analizi”. Banka, Mali ve Ekonomik Yorumlar Dergisi, 11, 47-56.

KAYA, V., ÇÖMLEKÇİ, İ., \& KARA, O. (2013). "Hisse Senedi Getirilerini Etkileyen Makroekonomik Değişkenler 2002-2012 Türkiye Örneği”. Dumlupinar University Journal of Social Science/Dumlupinar Üniversitesi Soysyal Bilimler Dergisi, (35).

KAYRAL, İ. E. (2020). "BİST Şehir Endeksleri ile Döviz Kurları Arasındaki İlişkinin İncelenmesi: Bir ARDL Sınır Testi Uygulaması”. IBAD Sosyal Bilimler Dergisi, (6), 272-284.

KISAKA, S. E., \& MWASARU, A. (2012). "The causal relationship between exchange rates and stock prices in Kenya". Research Journal of Finance and Accounting, 3(7), 121 130 .

KENDİRLİ, S., \& ÇANKAYA, M. (2016). "Dolar Kuru'nun Borsa İstanbul-30 Endeksi Üzerindeki Etkisi ve Aralarındaki Nedensellik İlişkisinin İncelenmesi”. Celal Bayar Üniversitesi Sosyal Bilimler Dergisi, 14(2).

MKK, Merkezi Kayıt Kuruluşu. (2020). "Yerli Yabancı (Pay Senedi) Analizi”, https://www.vap.org.tr/Saklama-Verileri/Sayfalar/Yerli-Yabanci-Pay-PiyasasiAnalizi.aspx

NAJAF, R., \& NAJAF, K. (2016). “A Study of Exchange Rates Movement and Stock Market Volatility”. Asian Journal of Management, Engineering \& Computer Sciences, 1(1), 32-38.

ÖZER, A., KAYA, A., \& ÖZER, N. (2011). "Hisse Senedi Fiyatları ile Makroekonomik Değişkenlerin Etkileşimi”. Dokuz Eylül Üniversitesi İktisadi ve İdari Bilimler Fakültesi Dergisi, 26(1).

POLAT, M. (2018). "Döviz Kurunun Firmaların Piyasa Değerine Etkisi: OECD Ülkeleri Üzerine Eşbütünleşme ve Nedensellik Analizi”. Ataturk University Journal of Economics \& Administrative Sciences, 32(2).

POLAT, M. A. (2020). “Döviz Kuru ile Enflasyon Arasındaki Geçişkenlik: Türkiye Örneğì”. Malatya Turgut Özal Üniversitesi İşletme ve Yönetim Bilimleri Dergisi, 1(2), 100-127.

RAMASAMY, B., \& YEUNG, M. C. (2005). "The Causality Between Stock Returns and Exchange Rates: Revisited”. Australian Economic Papers, 44(2), 162-169.

RJOUB, H., TÜRSOY, T., \& GÜNSEL, N. (2009). "The Effects of Macroeconomic Factors on Stock Returns: Istanbul Stock Market". Studies in Economics and Finance Vol. 26 No. 1, 2009 pp. 36-45

SAID, S. E., \& DICKEY, D. A. (1984). “Testing for Unit Roots in Autoregressive-Moving Average Models of Unknown Order”. Biometrika, 71(3), 599-607. 
SMYTH, R., \& NANDHA, M. (2003). "Bivariate Causality Between Exchange Rates and Stock Prices in South Asia”. Applied Economics Letters, 10(11), 699-704.

ŞAHIN, E., E., \& ÖZKAN, O. (2018). “Credit Default Swap, Exchange Rates and BİST 100 Index Relationship: Cointegration And Causality Analysis”, Hitit University Journal of Social Sciences Institute, 11(3),1939-1945. doi: 10.17218/hititsosbil.450178

ŞAHIN, İ., \& SEKMEN, F. (2013). “Türkiye'de Döviz Kuru Belirsizliğinin Hisse Senedi Getirilerine Etkisi”. Dumlupınar Üniversitesi Sosyal Bilimler Dergisi, (36).

SUI, L., \& SUN, L. (2016). "Spillover Effects Between Exchange Rates And Stock Prices: Evidence From BRICS around the recent global financial crisis". Research in International Business and Finance, 36, 459-471.

SÜMER, A. L. (2020). “2008 Sonrası TCMB Faiz Kararlarının Makroekonomik Etkilerinin Analizi”. Uluslararası Ekonomi Siyaset İnsan ve Toplum Bilimleri Dergisi, 3(1), 4974.

TIAN, G. G., \& MA, S. (2010). "The Relationship Between Stock Returns and the Foreign Exchange Rate: the ARDL Approach". Journal of the Asia Pacific economy, 15(4), 490-508.

TSAGKANOS, A., \& SIRIOPOULOS, C. (2013). “A Long-Run Relationship Between Stock Price Index and Exchange Rate: A Structural Nonparametric Cointegrating Regression Approach". Journal of International Financial Markets, Institutions and Money, 25, 106-118.

TSAI, I. C. (2012). "The Relationship Between Stock Price Index and Exchange Rate in Asian Markets: A Quantile Regression Approach”. Journal of International Financial Markets, Institutions and Money, 22(3), 609-621.

TURGUT, A. (2006). Finansal krizlerde 1mf'nin rolü ve önemi: 1997 Asya ve 2000-2001 Türkiye krizleri. Karamanoğlu Mehmetbey Üniversitesi Sosyal Ve Ekonomik Araştırmalar Dergisi, 2006(1), 1-14.

TÜRKIYYE BANKALAR BİRLİĞİ. (2002). Kur Rejimi Tercihi ve Türkiye. Erişim Adresi: https://www.tbb.org.tr/Dosyalar/Arastirma_ve_Raporlar/Kurrejimleri.doc

TCMB, Türkiye Cumhuriyet Merkez Bankası. (2020). 1 Hafta Repo. Erişim Adresi: https://www.tcmb.gov.tr/wps/wcm/connect/TR/TCMB+TR/Main+Menu/Temel+Faali yetler/Para+Politikasi/Merkez+Bankasi+Faiz+Oranlari/1+Hafta+Repo

TUİK, Türkiye İstatistik Kurumu. (2020). Tüketici Fiyat Endeksi, Eylül 2020, Erişim adresi: https://data.tuik.gov.tr/tr/display-bulletin/?bulletin=tuketici-fiyat-endeksieylul-2020-33870

TÜRSOY, T. (2017). “Causality Between Stock Prices and Exchange Rates in Turkey: Empirical Evidence From the ARDL Bounds Test and a Combined Cointegration Approach". International Journal of Financial Studies, 5(1), 8.

WALID, C., CHAKER, A., MASOOD, O., \& FRY, J. (2011). "Stock Market Volatility and Exchange Rates İn Emerging Countries: A Markov-state Switching Approach”. Emerging Markets Review, 12(3), 272-292. 
XIE, Z., CHEN, S. W., \& WU, A. C. (2020). "The Foreign Exchange and Stock Market Nexus: New International Evidence”. International Review of Economics \& Finance, 67, 240-266. 